\title{
Do Engineered Nanomaterials Affect Immune Responses by Interacting With Gut Microbiota?
}

\author{
Mingxing Tang ${ }^{1,2,3 \dagger}$, Shuo $\mathrm{Li}^{1,3 \dagger}$, Lan Wei ${ }^{2,4}$, Zhaohua $\mathrm{Hou}^{5}$, Jing $\mathrm{Qu}^{2 *}$ and $\mathrm{Liang} \mathrm{Li}^{2 *}$ \\ ${ }^{1}$ Huazhong University of Science and Technology Union Shenzhen Hospital, Shenzhen, China, 2 Institute of Biomedicine and \\ Biotechnology, Shenzhen Institutes of Advanced Technology, Chinese Academy of Sciences, Shenzhen, China, ${ }^{3}$ The 6th \\ Affiliated Hospital of Shenzhen University Health Science Center, Shenzhen, China, ${ }^{4}$ School of Biomedical Science and \\ Pharmacy, Faculty of Health and Medicine, Hunter Medical Research Institute, University of Newcastle, New Lambton \\ Heights, NSW, Australia, ${ }^{5}$ Department of Surgery, Sloan Kettering Institute Z427-D, Mortimer B. Zuckerman Research \\ Center, Memorial Sloan Kettering Cancer Center, New York, NY, United States
}

\section{OPEN ACCESS}

Edited by:

Diana Boraschi,

Shenzhen Institutes of Advanced Technology (CAS), China

Reviewed by: Benjamin Swartzwelter, Colorado State University,

United States

Mariusz Piotr Madej,

OcellO B.V., Netherlands

*Correspondence:

Liang Li

liang.li@siat.ac.cn

Jing Qu

jing.qu@siat.ac.cn

${ }^{t}$ These authors have contributed equally to this work and share first authorship

Specialty section: This article was submitted to Molecular Innate Immunity, a section of the journal

Frontiers in Immunology

Received: 23 March 2021

Accepted: 26 August 2021 Published: 14 September 2021

Citation:

Tang M, Li S, Wei L, Hou Z, Qu J and Li L (2021)

Do Engineered Nanomaterials Affect Immune Responses by Interacting With Gut Microbiota?

Front. Immunol. 12:684605. doi: 10.3389/fimmu.2021.684605
Engineered nanomaterials (ENMs) have been widely exploited in several industrial domains as well as our daily life, raising concern over their potential adverse effects. While in general ENMs do not seem to have detrimental effects on immunity or induce severe inflammation, their indirect effects on immunity are less known. In particular, since the gut microbiota has been tightly associated with human health and immunity, it is possible that ingested ENMs could affect intestinal immunity indirectly by modulating the microbial community composition and functions. In this perspective, we provide a few pieces of evidence and discuss a possible link connecting ENM exposure, gut microbiota and host immune response. Some experimental works suggest that excessive exposure to ENMs could reshape the gut microbiota, thereby modulating the epithelium integrity and the inflammatory state in the intestine. Within such microenvironment, numerous microbiota-derived components, including but not limited to SCFAs and LPS, may serve as important effectors responsible of the ENM effect on intestinal immunity. Therefore, the gut microbiota is implicated as a crucial regulator of the intestinal immunity upon ENM exposure. This calls for including gut microbiota analysis within future work to assess ENM biocompatibility and immunosafety. This also calls for refinement of future studies that should be designed more elaborately and realistically to mimic the human exposure situation.

Keywords: engineered nanomaterials (ENMs), gut microbiota, intestinal permeability, immunomodulation, bacterial components

\section{INTRODUCTION}

Unique properties including large surface area, high catalytic properties and antimicrobial efficacy confer to engineered nanomaterials (ENMs) a significant range of applications in nanomedicine and consumer products $(1,2)$, raising public concerns about their biosafety. For example, nanoparticulate $\mathrm{Ag}, \mathrm{TiO}_{2}, \mathrm{ZnO}$ and plastics are widely used in food additives (3), components of food packaging and containers $(4,5)$, and toothpaste (6). Oral exposure to these ENMs in our daily 
life is therefore likely through ingestion of food or water that deliberately or inadvertently contain ENMs. ENMs might therefore reach the gastro-intestinal tract (GIT) and interact with mucosal cells. Indeed, endocytosis of ENMs by intestinal epithelial cells (IECs) and various immune cells is observed using either conventional 2D in vitro models such as tumor cell lines $(7,8)$ or in vivo animal models $(9)$. Moreover, it has been reported that ENMs could modulate innate/inflammatory immune responses upon direct interactions with neutrophils, macrophages, dendritic cells (DCs) and the complement system (10-13). Upon ingestion, ENMs most likely also come in contact with gut microbiota, i.e., the population of microbes residing in the intestinal lumen and mucosa. It has been long known that the gut microbiota is essential for the development of the immune system and for immune homeostasis (14). Recent observations suggest that the ENM effects on innate/inflammatory responses largely depend on the co-presence of bacterial agents such as lipopolysaccharide (LPS) $(15,16)$. Thus, it is a logical assumption that ENMs could affect immunity by altering gut microbiota, a concept that is currently unexplored.

Herein, we provide an overview of the current state-of-theart, and discuss a hypothetical scenario in which ingested EMNs may affect host immunity by modulating the gut microbiota. From published in vivo studies in different models and with different ENMs, a high level of variability is found regarding the ENM effects on gut microbiota and local/systemic immunity (Table 1).

\section{LPS AND SCFAS: TWO REPRESENTATIVE MICROBIAL MOLECULES BRIDGING GUT MICROBIOTA AND INTESTINAL IMMUNITY}

Mounting evidence has highlighted the tremendous contribution of gut microbiota to human physiology (30-35). Within this microbiota-immune system interaction, a large amount of microbial metabolites and components serve as potent effectors to orchestrate their communication $(36,37)$. We will specifically discuss hereafter the immunomodulatory effects of short-chain fatty acids (SCFAs) and LPS. More comprehensive information is shown in Figure $\mathbf{1}$ and extensively discussed in other excellent reviews $(32,33,36-39)$. SCFAs are generated from indigestible oligosaccharides by gut commensals, including Lactobacillus, Bacteroides, Bifidobacterium, Feacalibacterium, etc. (40). LPS is the major membrane component of Gram-negative bacteria and has profound immunostimulatory and inflammatory capacity (41). The immunological effects of these microbiota-derived molecules are manifold, covering innate and adaptive immunity.

\section{Regulation of Innate Immunity}

As a physical barrier at the intestinal surface, IECs are equipped with an array of immune receptors to sense and integrate microbiota-derived metabolites and components for maintaining immune homeostasis. By activating G-proteincoupled-receptors (GPR41, GPR43, GPR109A) on IECs,
SCFAs can promote the activation of the NOD-like-receptorprotein 3 (NLRP3) inflammasome, inducing production of the homeostatic cytokine interleukin-18 (IL-18) (42). SCFAs can also stimulate goblet cell differentiation, mucin gene transcription and mucus secretion (43). Pattern recognition receptors (PRRs) on the IEC surface, such as Toll-like receptors (TLRs), can sense microbial antigens. Notably, a number of homeostatic mechanisms ensure immune tolerance towards commensals, such as the basolateral location of the LPS receptor TLR4 that allows binding and activation only to invading bacteria (44) and the constitutive expression of the anti-inflammatory IL-1R8, which binds to and inhibits TLR and IL-1 receptors (45).

Intriguingly, the commensal gut microbiota also interacts with IECs to maintain an effective gut barrier. SCFAs, particularly butyrate, have crucial roles in regulating tight junction (TJ) proteins via multifaceted signaling pathways (46), such as HIF-1 stabilization (47), and histone deacetylase (HDAC) inhibition (48). By contrast pathogenic E. coli Shigatoxins and LPS (49) could compromise the epithelial barrier by disrupting TJ. LPS increases intestinal epithelium permeability through the TLR4/MyD88/TGF- $\beta$ activated kinase 1 (TAK1)/ nuclear-factor- $\mathrm{\kappa B}(\mathrm{NF}-\kappa \mathrm{B})$ cascade in both in vitro and in vivo models (50).

Immunoregulation of gut microbiota also covers innate lymphoid cells (ILCs), a subpopulation of innate cells (natural killer cells, ILC1, ILC2, ILC3) specialized in recognizing and reacting to infectious challenges. SCFAs can modulate ILC3 proliferation and stimulate IL-22 production in an AKT/ STAT3-dependent manner. IL-22 promotes antimicrobial peptide (AMP) production, mucin secretion and colonization of commensal microbes (51).

Intestinal resident macrophages maintain the tissue homeostasis by removing senescent and anomalous cells, and contribute to tissue defense by eliminating invading pathogens and foreign objects. Upon binding to TLR4, LPS can promote inflammatory macrophage activation (M1 polarization), with the production of an array of inflammatory cytokines, IL-1 $\beta$, IL-6, IL-12 and tumor necrosis factor- $\alpha$ (TNF- $\alpha$ ) (52). Conversely, SCFA butyrate facilitates the anti-inflammatory/tissue-healing macrophage polarization, probably by activation of the $\mathrm{H} 3 \mathrm{~K} 9 /$ STAT6 signaling pathway (53).

\section{Regulation of Adaptive Immunity}

The impact of gut microbiota goes beyond the innate immunity, through its ability to affect the activation of antigen-presenting cells (APCs), which are the link between innate and adaptive immunity. APCs in the gut encompass resident DCs and tissue macrophages, which are involved in antigen presentation to naïve and primed $\mathrm{T}$ cells. Activation, maturation and functionality of DCs and macrophages can be influenced by LPS and SCFAs. As the major APCs in the intestine (54), macrophages can be regulated by microbial niacin and butyrate via activating GPR109A, which in turn increases production of anti-inflammatory IL-10 and AldehydeDehydrogenase-1-Family-Member-A1 (ALDH1A), and induces differentiation of T cells (55). LPS is a potent elicitor of DC 
TABLE 1 | Representative in vivo assays studying the impact of ENMs on gut microbiota and subsequent influences on intestinal immunity.

\begin{tabular}{|c|c|c|c|c|c|}
\hline Engineered NanoMaterials & Animal model & $\begin{array}{l}\text { Exposure } \\
\text { dose }\end{array}$ & $\begin{array}{l}\text { Exposure way } \\
\text { and duration }\end{array}$ & $\begin{array}{l}\text { Analysis methods of } \\
\text { gut microbiota }\end{array}$ & $\begin{array}{c}\text { Gut microbiota changes by ENM } \\
\text { treatment }\end{array}$ \\
\hline $\begin{array}{l}\text { Silver nanoparticles with a } \\
\text { diameter of } 55 \pm 3 \mathrm{~nm}\end{array}$ & $\begin{array}{l}3 \text { mo-old C57BL/6 } \\
\text { female mice }\end{array}$ & $\frac{\frac{0,11.4,114}{\operatorname{and} 1140 \mu \mathrm{g} /}}{\underline{\mathrm{kg} \mathrm{bw} / \mathrm{dy}}}$ & $\begin{array}{l}\text { Dietary exposure } \\
\text { for } 28 \text { days }\end{array}$ & $\begin{array}{l}\text { 16S rRNA Sequencing } \\
\text { of Bacterial DNA from } \\
\text { Fecal Samples }\end{array}$ & $\begin{array}{l}\text { Odoribacteraceae, Bacteroidaceae } \\
\text { and S24-7 family decreased while } \\
\text { Lactobacillaceae and } \\
\text { Lachnospiraceae increased }\end{array}$ \\
\hline $\begin{array}{l}\text { Silver nanoparticles with a } \\
\text { diameter of } 12 \pm 3 \mathrm{~nm}\end{array}$ & $\begin{array}{l}7 \text { wk-old CD-1 } \\
\text { (ICR) male mice }\end{array}$ & $\frac{2.5 \mathrm{mg} / \mathrm{kg} \mathrm{bw} /}{\underline{\mathrm{dy}}}$ & $\begin{array}{l}\text { Oral gavage daily } \\
\text { for } 7 \text { days }\end{array}$ & $\begin{array}{l}\text { Pyrosequencing of } 16 S \\
\text { rRNA genes in fecal } \\
\text { samples }\end{array}$ & $\begin{array}{l}\text { Firmicutes/Bacteroidetes ratio } \\
\text { reduced. Alistipes, Bacteroides } \\
\text { and Prevotella increased, while } \\
\text { Lactobacillus decreased }\end{array}$ \\
\hline $\begin{array}{l}\text { Silver nanoparticle with a } \\
\text { diameter of } 122 \mathrm{~nm}\end{array}$ & $\begin{array}{l}6 \text { wk-old BALB/c } \\
\text { male mice }\end{array}$ & $5 \mathrm{ng} / \mathrm{dy}$ & $\begin{array}{l}\text { Oral gavage daily } \\
\text { for } 4 \text { days }\end{array}$ & $\begin{array}{l}\text { A few specific bacteria } \\
\text { from the colon mucosa } \\
\text { were isolated and } \\
\text { counted by selective } \\
\text { plates }\end{array}$ & $\begin{array}{l}\text { Lactobacillus sp. decreased, while } \\
\text { Clostridium perfringens and } \\
\text { Escherichia coli increased but not } \\
\text { significantly } \\
\text { Lactobacillus sp. increased while } \\
\text { Clostridium perfringens and } \\
\text { Escherichia coli decreased }\end{array}$ \\
\hline $\begin{array}{l}\text { PVP-stabilized silver } \\
\text { nanoparticulate with a } \\
\text { diameter of } 14 \mathrm{~nm} \\
\text { PVP- or citrate-coated silver } \\
\text { nanoparticles with a diameter } \\
\text { of } 20 \text { and } 110 \mathrm{~nm} \\
\mathrm{TiO}_{2} \text { nanoparticles with a } \\
\text { diameter of } 17 \pm 2 \mathrm{~nm}\end{array}$ & $\begin{array}{l}4 \text { wk-old Wistar } \\
\text { Hannover Galas } \\
\text { rats } \\
10-12 \text { wk-old } \\
\text { C57BL/6NCrl male } \\
\text { mice } \\
7 \text { wk-old CD-1 } \\
\text { (ICR) male mice }\end{array}$ & $\begin{array}{l}\frac{2.25,4.5 \text { or } 9}{\mathrm{mg} / \mathrm{kg} \mathrm{bw} / \mathrm{dy}} \\
\frac{10 \mathrm{mg} / \mathrm{kg} \mathrm{bw} /}{\underline{\mathrm{dy}}} \\
\frac{2.5 \mathrm{mg} / \mathrm{kg} \mathrm{bw} /}{\underline{\mathrm{dy}}}\end{array}$ & $\begin{array}{l}\text { Oral gavage daily } \\
\text { for } 14 \text { days and } 28 \\
\text { days } \\
\text { Oral gavage daily } \\
\text { for } 28 \text { days } \\
\text { Oral gavage daily } \\
\text { for } 7 \text { days }\end{array}$ & $\begin{array}{l}\text { Bacterial phyla in } \\
\text { caecum content were } \\
\text { quantified by qPCR } \\
16 S \text { rRNA sequencing } \\
\text { of contents in the cecal } \\
\text { tips } \\
\text { Pyrosequencing of } 16 S \\
\text { rRNA genes in fecal } \\
\text { samples }\end{array}$ & No significant change \\
\hline
\end{tabular}

Spherical anatase $\mathrm{TiO}_{2}$ 8 wk-old C57BL/6 $\quad 100 \mathrm{mg} / \mathrm{kg} \mathrm{bw} /$ Oral gavage daily nanoparticles with a diameter male mice

of $20 \mathrm{~nm}$ in water, of $134 \pm 22$

$\mathrm{nm}$ in intestinal fluid

Edged conner rutile $\mathrm{TiO}_{2}$

nanoparticles with a diameter
of $16 \mathrm{~nm}$ in water, of $148 \pm 30$

in gastric fluid, of $361 \pm 8 \mathrm{~nm}$

in intestinal fluid

Spherical anatase $\mathrm{TiO}_{2}$

$\begin{array}{ll}\text { Spherical anatase } \mathrm{TiO}_{2} & 3 \text { wk-old Sprague } \\ \text { nanoparticles with a diameter } & \text { Dawley rats } \\ 29 \pm 9 \mathrm{~nm} & \end{array}$

$\begin{array}{lll}3 \text { wk-old Sprague- } & \underline{0,2,10,50} & \begin{array}{l}\text { Oral gavage daily } \\ \text { Dawley rats }\end{array} \\ \underline{m g / k g ~ b w} & \text { for } 30 \text { days }\end{array}$

16S rRNA Sequencing Bacteroides and Akkermansia of Bacterial DNA from increased

Fecal Samples

Escherichia-Shigella and Rhodococcus increased, whil decreased

(and

16S rRNA Sequencing
of Bacterial DNA from
Fecal Samples

Increased abundance of $L$.

gasseri, Turicibacter, and $L$. abundance of Veillonella

ZnO nanoparticles with a 28 dy 150, 300, or Dietary exposure diameter of average $71.61 \mathrm{~nm}$ piglets $450 \mathrm{mg} / \mathrm{kg}$ in for 21 days

The cecal, colonic and E. coli decreased rectal contents were spread on selective
plates to assess $E$. plates to assess
coli, Salmonella, Lactobacillus, and Bacillus bifidus

\section{Immune markers} Serum C-reactive protein level goblet cells, glycocalyx and colon

Blood cell level, serum lymphocyte level. colon leng disease activity index (DA), histology of colon; intestin TNF- $\alpha$ in small bowel and colo

Stool consistence; colon leng and weight; colon epithelia histology; myeloperoxidase activity in the colon. Colon Presence of ulcers,

hemorrhage, fecal blood, and diarrhea.

Histology of liver, kidney, ileum and myocardium. Twenty-fourhour urine and feces.

Blood cell level, serum lymphocyte level. colon length, histology of colon; intestinal permeability; IL-1 $\beta, \mid L-6$ and TNF- $\alpha$ in small bowel and co

Histology of liver, spleen, kidney, lung, heart, brain, jejunum and colon. NP
deposition in these organs

Body weight; LPS and shortchain fatty acids content in the feces; colon histology; feca metabolites; presence of
glutathione, glutathione peroxidase, lipid peroxidation products, superoxide dismutase, and sulfhydryl

groups in tissue homogenates; Inflammatory cytokines in ser Histology of the jejunum, duodenum and ileum; serum
cytokines and immunoglobins
Clinical effect/Immune response

overt effect on body weight gain the intestinal histology as well as the serum Creactive protein level.

The level of blood cells and lymphocytes was increased, Body weight decreased and colo length was shortened by Ag NP; The epithelial architecture and crypts in colon was significantly increased: Pro-inflammatory cytokines: IL-1 $1 \mathrm{~L}-6$ and TNF-a were upregulated.

NanoAg1 displayed weaker anti-inflammatory (19) effect and alleviated the TNBS-induced severe colonic injury.

NanoAg2 significantly attenuated DSSleviated the TNBSinduced severe colonic injury.

No overt effect on body weight gain, organ weight, organ histology and leucocyte infiltration
Not studied

$\mathrm{TiO}_{2}$ ENMs were deposited in the stomach and the colon: no effect on body weight, no significant change in DAl index and colon ength, loss and shortening of crypts, inflammatory cell infiltration and mucosa erosions but a few inflammatory cells scattered whin duodenal and colonic intact: II-1 1 level was increased in the smal bowel and colon. No effect on body weight or histology of key organs

Intestinal villi length increased and villus epithelium cells became irregularly arranged

Accumulation of malondialdehyde and decreased activity of superoxide dismutase were detected in colon tissues; Increased concentration of IL-6 in the serum. The inflammatory cells infiltrated in colon epithelium.

Significant improvements in average daily weight gain, average daily feed intake an diarrhea rate was reduced. The villus height in the jejunum, duodenum and leum was increased. The blood concentration of IgA serum concentrations of IL- 6 and TNF- $\alpha$ was increased; while the blood concentration of IgM was decreased.

,


TABLE 1 | Continued

\begin{tabular}{|c|c|c|c|c|c|c|c|c|}
\hline Engineered NanoMaterials & Animal model & $\begin{array}{l}\text { Exposure } \\
\text { dose }\end{array}$ & $\begin{array}{l}\text { Exposure way } \\
\text { and duration }\end{array}$ & $\begin{array}{l}\text { Analysis methods of } \\
\text { gut microbiota }\end{array}$ & $\begin{array}{c}\text { Gut microbiota changes by ENM } \\
\text { treatment }\end{array}$ & Immune markers & Clinical effect/Immune response & References \\
\hline $\begin{array}{l}\text { ZnO nanoparticles with a } \\
\text { diameter of } 23-25 \mathrm{~nm}\end{array}$ & $\begin{array}{l}27 \text { dy-old weaned } \\
\text { piglets }\end{array}$ & $\begin{array}{l}600 \mathrm{mg} / \mathrm{kg} \text { in } \\
\text { diet }\end{array}$ & $\begin{array}{l}\text { Dietary exposure } \\
\text { for } 14 \text { days }\end{array}$ & $\begin{array}{l}\text { 16S rRNA sequencing } \\
\text { of the intestinal } \\
\text { contents }\end{array}$ & $\begin{array}{l}\text { Lactobacillus increased while } \\
\text { Prevotella and Oscillospira } \\
\text { decreased in the colon }\end{array}$ & $\begin{array}{l}\text { Histology of jejunal tissue; gene } \\
\text { expression of pro-inflammatory } \\
\text { cytokines, cell proliferation } \\
\text { markers, antioxidant markers, } \\
\text { tight junction proteins and cell } \\
\text { death markers in the jejunal } \\
\text { tissue }\end{array}$ & $\begin{array}{l}\text { The diarrhea incidence was reduced; average } \\
\text { daily gain and feed intake were unaltered; } \\
\text { villus height as well as the ratio of villus height } \\
\text { to crypt depth was increased; the expression } \\
\text { of antioxidant enzymes and tight junction in } \\
\text { the jejunal tissues was increased significantly; } \\
\text { the expression of cell proliferation markers } \\
\text { was increased; the expression of pro- } \\
\text { inflammatory markers was reduced. }\end{array}$ & (25) \\
\hline $\begin{array}{l}\text { SWCNT with a diameter of } \\
1 \mathrm{~nm} \text { and } \mathrm{a} \text { length of } 1-5 \mu \mathrm{m}\end{array}$ & $\begin{array}{l}7 \text { wk-old CD-1 } \\
\text { (ICR) male mice }\end{array}$ & $\begin{array}{l}0.05,0.5, \text { and } \\
2.5 \mathrm{mg} \mathrm{kg} / \mathrm{bw} / \\
\mathrm{dy}\end{array}$ & $\begin{array}{l}\text { Oral gavage daily } \\
\text { for } 7 \text { days }\end{array}$ & $\begin{array}{l}16 \mathrm{~S} \text { rRNA sequencing } \\
\text { of fecal samples }\end{array}$ & $\begin{array}{l}\text { Bacteroides, Prevotella, and } \\
\text { Alistipes increased, while } \\
\text { Bacteroidales, Lachnospriaceae } \\
\text { and Lactobacillus decreased }\end{array}$ & $\begin{array}{l}\text { Intestine histology, intestinal } \\
\text { epithelium permeability, cytokine } \\
\text { production in both duodenum } \\
\text { and colon and lymphocyte } \\
\text { abundance in the serum. }\end{array}$ & $\begin{array}{l}\text { Ulceration, crypt damage, and inflammatory } \\
\text { cell infiltration were observed in the } \\
\text { duodenum and colon. The intestinal } \\
\text { permeability was significantly increased. IL- } \\
1 \beta, \text { IL-6, and TNF- } \alpha \text { increased in the } \\
\text { duodenum and the colon. White blood cell, } \\
\text { lymphocytes, and intermediate cell counts } \\
\text { significantly elevated in the serum. }\end{array}$ & (26) \\
\hline $\begin{array}{l}\text { MWCNT with a diameter of } 8 \\
\pm 1 \mathrm{~nm} \text { and a length of } 0.5-2 \\
\mu \mathrm{m}\end{array}$ & & $\begin{array}{l}2.5 \mathrm{mg} \mathrm{kg} / \mathrm{bw} / \\
\text { day }\end{array}$ & & $\begin{array}{l}16 \mathrm{~S} \text { rRNA sequencing } \\
\text { of fecal samples }\end{array}$ & $\begin{array}{l}\text { Bacteroides, Prevotella, Alistipes, } \\
\text { and Ruminococcaceae increased, } \\
\text { whereas Bacteroidales, } \\
\text { Lachnospriaceae and } \\
\text { Lactobacillus decreased }\end{array}$ & & 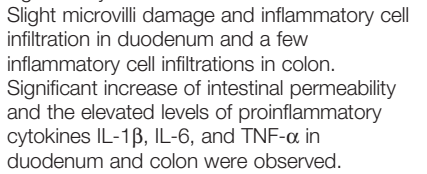 & \\
\hline $\begin{array}{l}\text { Graphene oxide nanoparticles } \\
\text { with a thickness of } 1-2 \mu \mathrm{m} \\
\text { and a dimension area of } 1-14 \\
\mu \mathrm{m}^{2}\end{array}$ & & $\begin{array}{l}2.5 \mathrm{mg} \mathrm{kg} / \mathrm{bw} / \\
\mathrm{dy}\end{array}$ & & $\begin{array}{l}16 \mathrm{~S} \text { rRNA sequencing } \\
\text { of fecal samples }\end{array}$ & $\begin{array}{l}\text { Lachnospriaceae, Lactobacillus, } \\
\text { Ruminococcus, Alistipes, } \\
\text { Oscillibactyer, and Prevotella } \\
\text { increased; while Bacteroidales and } \\
\text { Bacteroides decreased }\end{array}$ & & $\begin{array}{l}\text { Slightly pathological changes of epithelium } \\
\text { loss and inflammatory cell infiltration in } \\
\text { duodenum. Significant increase of intestinal } \\
\text { permeability and the elevated levels of } \\
\text { proinflammatory cytokines IL- } 1 \beta \text {, IL-6, and } \\
\text { TNF- } \alpha \text { in duodenum and colon were } \\
\text { observed. }\end{array}$ & \\
\hline $\begin{array}{l}\text { Lysine-modified SWCNT with a } \\
\text { length of } 400 \mathrm{~nm} \text { and a } \\
\text { diameter of } 2-3 \mathrm{~nm}\end{array}$ & $\begin{array}{l}23-30 \text { dy-old } \\
\text { BALB/c mice }\end{array}$ & $4.25 \mathrm{mg} / \mathrm{wk}$ & $\begin{array}{l}\text { Oral gavage or } \\
\text { intraperitoneal } \\
\text { dosing weekly for } 7 \\
\text { or } 8 \text { weeks }\end{array}$ & $\begin{array}{l}16 \mathrm{~S} \text { rRNA sequencing } \\
\text { of fecal samples }\end{array}$ & $\begin{array}{l}\text { The } \alpha \text { - and } \beta \text {-diversity of the } \\
\text { mouse microbiota reduced in the } \\
\text { cecum but not in colon or ileum. }\end{array}$ & $\begin{array}{l}\text { Body weight, liver and kidney } \\
\text { weight. }\end{array}$ & $\begin{array}{l}\text { No overt effect on body weight as well as } \\
\text { liver and kidney weights }\end{array}$ & (27) \\
\hline $\begin{array}{l}\text { Polyethylene microplastics with } \\
\text { a diameter of } 10-150 \mu \mathrm{m}\end{array}$ & C57BL/6 mice & $\begin{array}{l}6,60, \text { and } 600 \\
\mu \mathrm{g} / \mathrm{dy}\end{array}$ & $\begin{array}{l}\text { Dietary exposure } \\
\text { for } 5 \text { weeks }\end{array}$ & $\begin{array}{l}16 \mathrm{~S} \text { rRNA sequencing } \\
\text { of fecal samples }\end{array}$ & $\begin{array}{l}\text { The } \alpha \text { - and } \beta \text {-diversity of the } \\
\text { mouse microbiota increased. } \\
\text { Staphylococcus increased, while } \\
\text { Parabacteroides decreased }\end{array}$ & $\begin{array}{l}\text { Serum cytokine; T cells in the } \\
\text { spleen; TLR4, AP-1, and IRF5 } \\
\text { expression; intestinal histology. }\end{array}$ & $\begin{array}{l}\text { Serum concentrations of IL-1 } \alpha \text { increased; the } \\
\text { percentage of Th17 and Tregs cells among } \\
\text { CD4 } 4^{+} \text {cells decreased; edema occurred and } \\
\text { lymphocyte and plasma cell infiltration was } \\
\text { observed in the lamina propria of the colon } \\
\text { and duodenum; TLR4, AP-1, and IRF5 } \\
\text { expression significantly increased in the colon } \\
\text { and duodenum. }\end{array}$ & (28) \\
\hline $\begin{array}{l}\text { Cuboid CuO nanoparticles } \\
\text { with a dimension area of } 20 \\
\text { nm by } 50 \mathrm{~nm}\end{array}$ & $\begin{array}{l}\text { Eisenia fetida with } \\
\text { a weight range } \\
\text { between } 300 \text { and } \\
600 \mathrm{mg}\end{array}$ & 160 mg/kg soil & $\begin{array}{l}\text { Exposure to soil } \\
\text { containing ENMs } \\
\text { for } 28 \text { days }\end{array}$ & $\begin{array}{l}16 \mathrm{~S} \text { rRNA sequencing } \\
\text { of microbiota in gut } \\
\text { tissue }\end{array}$ & $\begin{array}{l}\text { Candidatus Lumbricincola and } \\
\text { Luteolibacter decreased }\end{array}$ & $\begin{array}{l}\text { Histology of the gut epithelium } \\
\text { and longitudinal muscle tissue; } \\
\text { expression of coelomic cytolytic } \\
\text { factor, lysenin/fetidin and } \\
\text { lysozyme. }\end{array}$ & $\begin{array}{l}\text { No overt effect on tissue integrity, and } \\
\text { immune responses }\end{array}$ & (29) \\
\hline
\end{tabular}

Doses relevant for human exposure level are marked using underline. AP-1, activating protein-1; BW, body weight; CuO, copper oxide; DSS, dextran sulfate sodium; Dy, day; GIT, gastrointestinal tract; IL, interleukin; Ig, immunoglobin; IRF5, interferon regulatory factor 5; LPS, lipopolysaccharide; Mo, month; MWCNT, multiple-walled carbon nanotubes; PVP, polyvinyl pyrrolidone; SWCNT, single-walled carbon nanotubes; Th17, Thelper type 17; TNBS, trinitrobenzene sulfonic acid; TLR4, Toll-like receptor 4; TNF, tumour necrosis factor; Wk, week; ZnO, zinc oxide. 


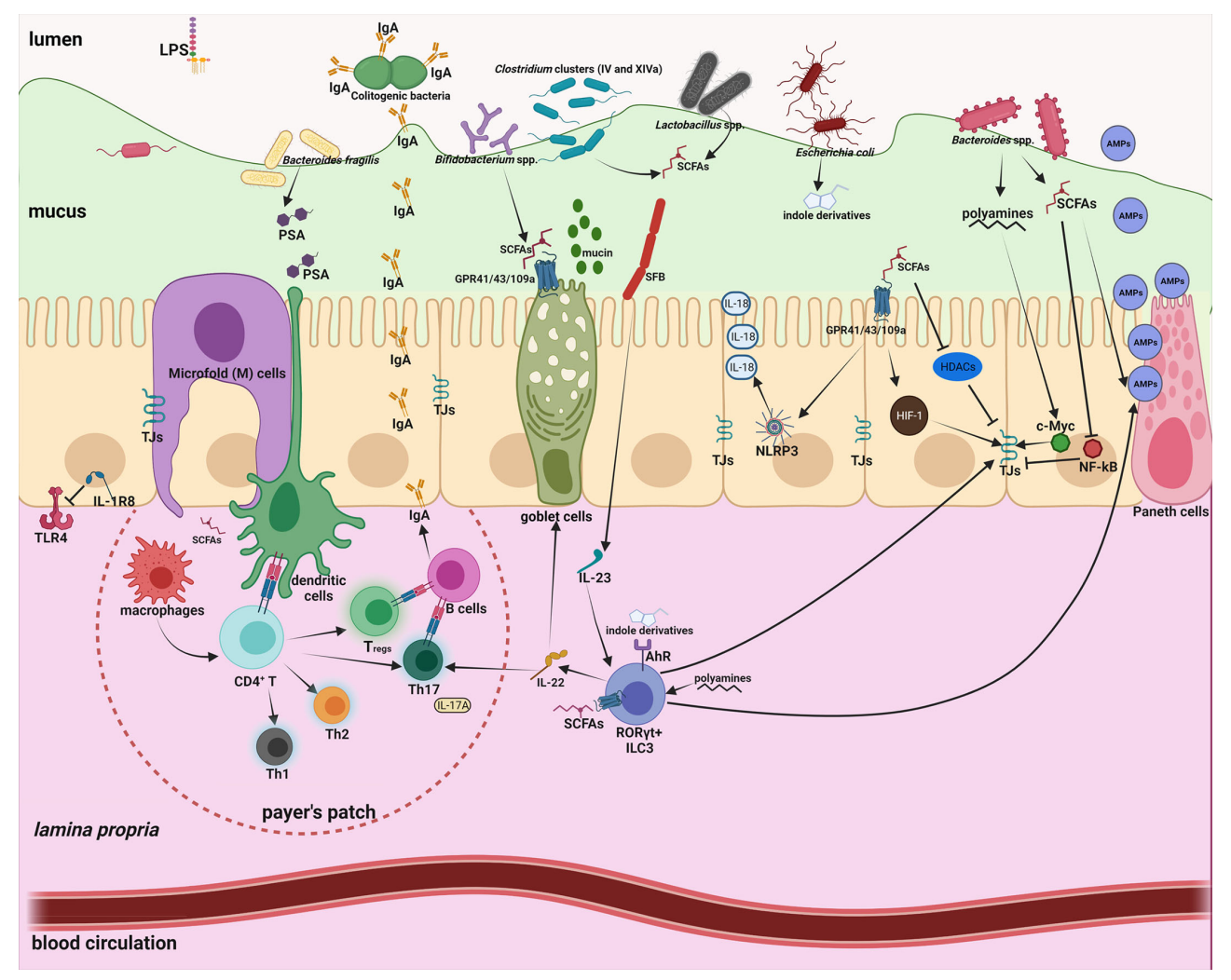

FIGURE 1 | Intestinal homeostasis is tightly controlled by gut microbiota through a large number of microbial metabolites/components. Intestinal mucus not only provides a habitat for bacterial colonization but also serves as a lubricant barrier to restrict most gut microbes in the outer layer. Microfold (M) cells above the Peyer's patch are essential to transport microbiota-derived metabolites/components to maintain the homeostasis of the mucosal immune system. 1) The effects of shortchain-fatty-acids (SCFAs) are manifold, including enhanced mucus production; inhibition of nuclear factor- $\kappa B$ (NF- $\kappa B$ ); activation of NLR-family-pyrin-domaincontaining-3 (NLRP3) inflammasomes and subsequent production of interleukin-18 (IL-18); enhanced antimicrobial peptide (AMP) production; polarization of antiinflammatory macrophages; increased Immunoglobulin A (IgA) secretion; reduced expression of T cell-activating molecules on antigen-presenting cells; and increased number and function of colonic regulatory $T\left(T_{\text {regs }}\right)$ cells. 2) Polyamines can activate ROR ${ }^{\gamma t+}$ group 3 innate lymphoid cells (ILC3) and induce production of IL-22, which promote mucus and AMP secretion, and ensure commensal compartmentalization from the intestinal epithelium. 3) Indole derivatives produced by gut commensals can stimulate Aryl-Hydrocarbon-Receptor (AhR) to activate ILC3 and fortify the epithelium barrier function. 4) Polysaccharide A (PSA) from Bacteroides fragilis is taken up by DCs, processed and presented to naive CD4 ${ }^{+} \mathrm{T}$ cells, inducing the expansion of FOXP3 ${ }^{+} \mathrm{T}_{\text {reg }}$ cells. 5) Attachment of segmented filamentous bacteria (SFB) to the epithelium enhances differentiation and expansion of CD4 ${ }^{+}$Th17 cells. Foxp3 ${ }^{+}$Treg cells and Th17 cells localize in the Peyer's patches, and induce B cell class-switch and IgA production, which in turn remodels microbiota. 6) Basolateral location of the LPS receptor TLR4 on IECs and expression of the anti-inflammatory IL-1R8 allow proper immune tolerance.

migration and maturation by activating mitogen-activated protein kinase (MAPK) and NF- $\mathrm{KB}$ signaling pathways (56). SCFAs can block the DC generation from bone marrow stem cells (57), and down-regulate expression of the T cell-stimulatory proteins CD80, CD83 and major-histocompatibility-complex class II (MHCII) (58).

Through its effects on APCs that produce several cytokines necessary for $\mathrm{T}$ cell activation, the gut microbiota is also involved in differentiation of naïve $\mathrm{CD}^{+} \mathrm{T}$ cells into defined subsets, including $\mathrm{T}$ helper (Th1, Th2 and Th17) and regulatory $\mathrm{T}$ cells $\left(\mathrm{T}_{\text {regs }}\right)$. Inhibition of HDAC by SCFAs can regulate the mTORS6K pathway required for generation of Th17, Th1, and IL- $10^{+} \mathrm{T}$ cells (59). $\mathrm{T}_{\text {regs }}$ have important anti-inflammatory roles, allowing the immune system to tolerate antigens derived from gut microbiota and diet. Through binding to GPR43, SCFAs can stimulate $\mathrm{T}_{\text {regs }}$ proliferation (60). Additionally, SCFAs control the expression of genes necessary for plasma B cell differentiation and Immunoglobulin A (IgA) production (61). As the largest class of immunoglobulins in the intestinal mucosa, IgA targets microbial antigens and preferentially coats colitogenic bacteria, therefore preventing inflammation and perturbation of intestinal homeostasis (62).

\section{NUMEROUS ENMS COULD RESHAPE THE GUT MICROBIOTA SIGNATURE BUT IT IS NOT A GENERAL EFFECT}

ENMs might interact with gut microbes in different manners (Figure 2). Of special concern is the intrinsic antimicrobial potency of some ENMs. Nanoparticulate $\mathrm{Au}, \mathrm{Ag}, \mathrm{TiO}_{2}$ and 


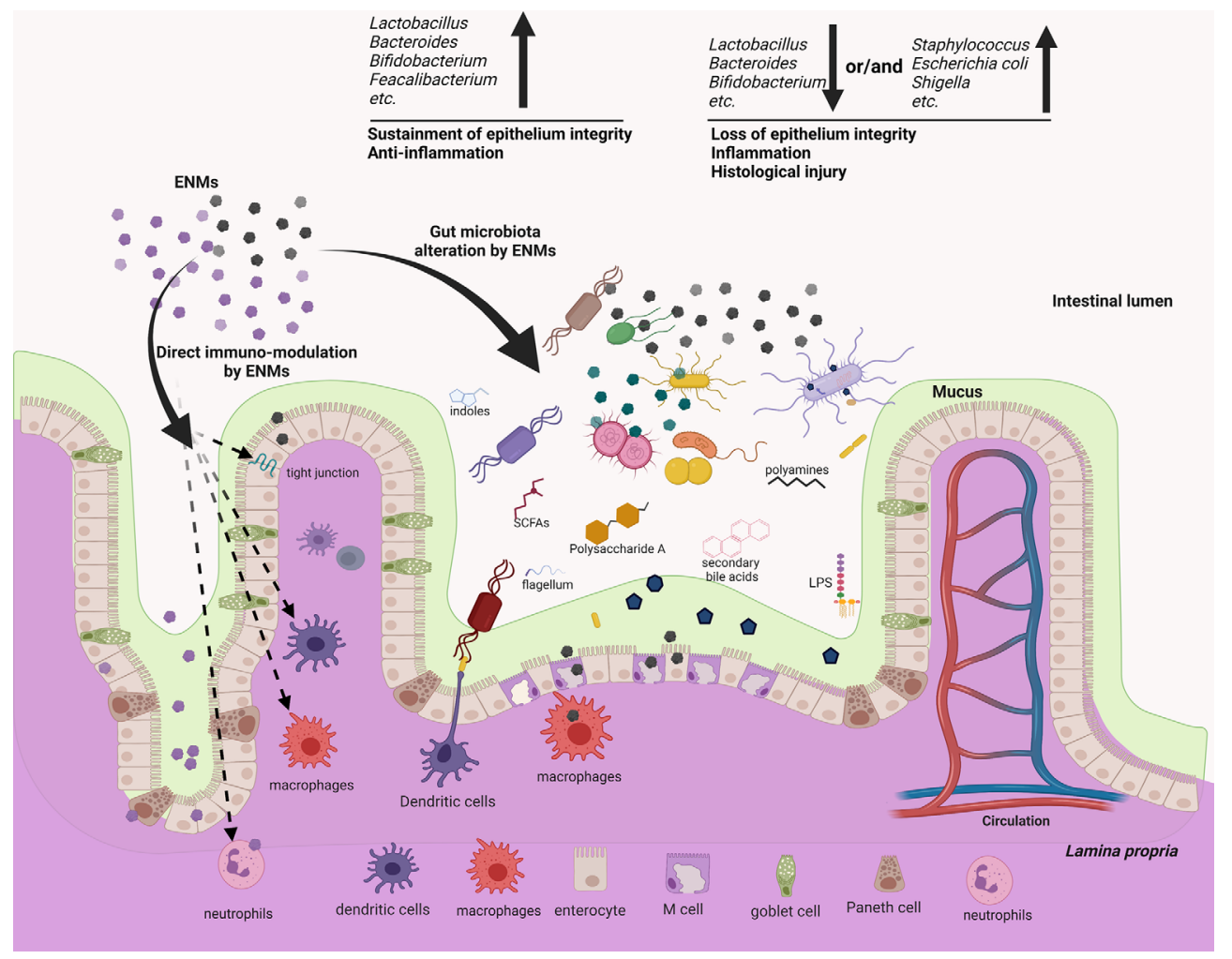

FIGURE 2 | ENMs could not only modulate several components of the mucosal immune systems directly, but also reshape the gut microbiota, which may potentially act as an alternative but important regulator to mediate the immuno-modulatory effects of ENMs. ENMs could accumulate and directly interact with neutrophils, macrophages, dendritic cells (DCs) and the complement system to modulate innate/inflammatory immune responses. On the other hand, several metallic and non-metallic ENMs are proved to be bactericidal, either impairing the bacterial membrane, or causing intracellular oxidative stress, or generating genotoxicity. As responses to the ENM bactericidal effects, members of gut microbiota may rapidly develop resistance, but the associated molecular strategies and efficacy often differ among distinct members. Many in vitro and in vivo assays showed that ENMs can alter the gut microbiota profile, enrich the relative abundance of pathogens or decrease that of gut commensals. This effect often associates with intestinal inflammation and tissue injury. While some ENMs could increase gut commensals, which in turn exert anti-inflammatory effects. Conversely, a few works show that the gut microbiota remains resilient following oral exposure to ENMs, indicating that the ENM effect on gut microbiota/mucosal immunity is not general.

$\mathrm{ZnO}$ can exert bactericidal activity by disrupting the bacterial membrane $(63,64)$, inducing intracellular reactive oxygen species $(64,65)$ and causing direct genotoxicity (66). Conversely, iron oxide and graphene ENMs can promote the growth of some bacterial species, with mechanisms still largely unknown $(67,68)$. Adding to the complexity is that many gut microbes could rapidly develop strategies to resist ENM bactericidal actions (69). Gram-negative bacteria are thought to be more tolerant to ENMs, in that a lower amount of the negatively charged peptidoglycan may be less effective in trapping the positively-charged metal ions, while other studies argue that Gram-positive bacteria have thicker membranes to ensure stronger protection $(69,70)$. The resistance mechanism to ENMs could be specific at the bacterial species/strain level. The gut microbiota remodeling effect of ENMs has been substantiated by a panel of in vivo assays. For instance, dietary Ag ENMs for mice decreased Odoribacteraceae, Bacteroidaceae and the S24-7 family while increasing Lactobacillaceae and Lachnospiraceae (17). Oral gavage of $\mathrm{TiO}_{2}$ ENMs in mice also modulated the gut microbiota, with Bacteroides and
Akkermansia increased (22). Oral administration of nonmetallic single-walled carbon nanotubes (SWCNTs) modestly altered the $\alpha$ - and $\beta$-diversity of the mouse microbiome (27). The modulation of animal gut microbiota by other ENMs is systemically summarized in recent reviews, which include nanoparticulate plastics, graphene oxide, multi-walled carbon nanotubes (MWCNT), SWCNT, Ag, $\mathrm{ZnO}, \mathrm{MoO}_{3}, \mathrm{MoS}_{2}, \mathrm{TiO}_{2}$, $\mathrm{CuO}$ and $\mathrm{SiO}_{2}(5,71,72)$. Numerous in vitro assays also validate the ENM modulatory effect on gut microbiota samples $(68,73-$ 75). Importantly, there appears to be no consensus effect, as multiple ENM-related factors (dose, physicochemical nature, particle size, surface charge, shape and stability) might dictate their modulatory mechanisms and efficacy $(64,76)$. In addition, the gut microbiota signature varies among individuals, and even within the same subject it changes with time, food intake and health conditions (77-79).

One may suspect the modulatory effect of ENMs on gut microbiota. Because the link between immunity and microbiota is bidirectional (32), could it be possible that ENMs affect immunity and as a consequence the microbiota? Indeed, 
ENMs could accumulate in the intestine, favor inflammatory responses and impair the barrier function, including IEC apoptosis, tight junction opening, decreased AMP production, Th1/ $\mathrm{T}_{\text {regs }}$ imbalance, aberrant IgA secretion and inflammatory activation of macrophages (72). In this situation, the gut microbiota can be in turn altered by the mucosal immunity. But, a considerable number of ENMs (Ag, SWCNT, $\mathrm{CuO}, \mathrm{TiO}_{2}$ ) are shown to alter the gut microbiota without inducing any detectable changes in intestinal immunity $(17,22,27,29)$. These data suggest that ENMs may cooperate with the mucosal immunity to modulate the gut microbiota.

\section{THE POTENTIAL EFFECT OF ENM- ALTERED MICROBIOTA ON INTESTINAL INFLAMMATION}

As discussed above, microbiota-derived metabolites such as SCFAs have important roles in the regulation of gut immunity (Figure 1), while ENM exposure that reduces SCFA-producing bacteria may perturb the immune homeostasis and cause inflammation (Table 1). Indeed, gut microbiota dysbiosis appears to tightly associate with inflammatory bowel disease (IBD), a chronic and relapsing inflammatory disorder of the intestine (80). This link has been observed in several in vivo assays that model GIT exposure to ENMs. Oral administration of Ag ENM (2.5 mg/kg body weight daily) in mice profoundly reduced the Firmicutes to Bacteroidetes ratio, specifically due to an increase in Alistipes, Bacteroides and Prevotella, and a significant decrease in SCFA-producing Lactobacillus. The altered microbiota could cause some IBD-like symptoms, including disrupted epithelium structure, increased intestinal permeability and upregulation of inflammatory cytokines (IL$1 \beta$, IL- 6 and TNF- $\alpha$ ) (18). In the same study, oral gavage of $\mathrm{TiO}_{2}$ ENMs ( $2.5 \mathrm{mg} / \mathrm{kg}$ body weight daily) significantly decreased the probiotic Bacteroides and triggered a low-grade colonic inflammation (18). Likewise, administration of SWCNT, MWCNT and graphene oxide ENMs $(2.5 \mathrm{mg} / \mathrm{kg}$ body weight daily) in mice disrupted the gut microbiota signature, with commensal Lactobacillus and Bacteroides decreased. The exposed mice displayed tissue injury, increased intestinal permeability and elevated production of inflammatory IL-1 $\beta$, IL-6, and TNF- $\alpha$ (26).

Moreover, enrichment of pathogens and associated virulence factors following ENM administration could also cause intestinal inflammation (81). The work of Chen et al. showed that oral administration of $\mathrm{TiO}_{2}$ ENMs (50 mg/kg body weight) in rats decreased the number of goblet cells, elicited immune cell infiltration and mitochondrial abnormalities in the colon tissues, suggesting redox imbalance and inflammation. $\mathrm{TiO}_{2} \mathrm{ENM}$ treatment remarkably affected the fecal metabolite profile, and particularly enriched the LPS content (23). In another work, oral gavage of $\mathrm{TiO}_{2}$ ENM (100 mg/kg body weight daily) in mice impaired the intestinal microvilli structure, and increased Escherichia and Shigella, two potential pathogens for elicitation of intestinal inflammation (22). Dietary nanoplastics (600 $\mu \mathrm{g}$ daily) for mice significantly increased pathogenic Staphylococcus abundance alongside a decrease in Parabacteroides (28). The ENM-feeding group displayed a chronic intestinal inflammation, such as increased serum IL- $1 \alpha$, abnormal ratio of Th17 and $\mathrm{T}_{\text {regs }}$ among $\mathrm{CD}^{+}$cells, infiltration of lymphocytes and plasma B cells in the lamina propria, and higher expression of inflammatory markers (TLR4, AP-1, and IRF5) (28). In these cases, ENMs may enrich opportunistic pathogens or liberate the membrane-bound PAMPs from bacterial cells (82). The inflammatory antigens, such as LPS, exotoxin and flagellin, would bind to PRRs on IECs and immune cells, thus activating inflammatory pathways and promoting an excessive intestinal inflammation (83-86). However, most of these in vivo studies based on animal models rarely simulated the realistic human exposure condition. Table 1 details such shortcomings: either subjects were exposed to an excessive dose of ENMs, or ENMs were administered alone without food which is not a real-life fashion. Whether ENMs were contaminated by LPS was not checked, either.

There is no general effect of ENMs on gut microbiota and intestinal immunity. Contrary to the aforementioned adverse effects, other studies showed that ENM ingestion can increase commensal microbes and exert anti-inflammatory effects. Dietary $\mathrm{ZnO}$ ENMs (600 $\mathrm{mg} / \mathrm{kg}$ food) for weaned piglets increased Lactobacillus, leading to upregulation of tight junction proteins and antioxidant enzymes, and decreased expression of inflammatory interferon- $\gamma$ (IFN- $\gamma$ ), IL- $1 \beta$, TNF- $\alpha$ and NF- $\kappa B$ (25). Similarly, oral gavage of Ag ENMs (5ng daily) attenuated the dextran sodium sulfate (DSS)-induced IBD symptoms in mice, probably by increasing Lactobacillus and decreasing Clostridium perfringens and Escherichia coli (19). Enrichment of Lactobacillus was found in these works, again highlighting the protective role of SCFA-producers in epithelium integrity and anti-inflammatory responses.

Strikingly, several studies found no significant effect of ENMs (Au, $\mathrm{CuO}, \mathrm{Ag}$ and lysine-modified SWCNTs) on intestinal immunity $(17,20,21,27,29,87)$. One possibility is that most ENMs may be rapidly excreted following ingestion, so few accumulate in the GIT and they are insufficient to modulate the immune responses. Indeed, 270-day consecutive dietary supplementation with $\mathrm{ZnO}$ ENMs (1600 $\mathrm{mg} / \mathrm{kg}$ food) for mice revealed no detectable ENM distribution in the GIT (88). Hence, this work indicates that there is no general effect regarding the biodistribution and accumulation, it should be specific to each ENM. Additionally, the mucus layer that is mainly composed of highly-glycosylated secreted proteins overlying the intestinal epithelium could trap ENMs and minimize their contact with gut microbes and mucosal cells (8). This can explain why the modulatory effect of ENMs on gut microbes in vitro is always greater than that in vivo. When the earthworms were exposed to soil with $\mathrm{CuO}$ or $\mathrm{Ag}$ ENMs, the gut microbiota remained largely resilient, whereas both ENMs significantly changed the soil bacterial community composition (89). Moreover, though some ENMs can modify the gut microbiota, members of the core commensal consortium are not affected; or the roles of redundant symbionts affected by ENMs could be compensated by other unchanged commensals. For example, exposure of earthworms to soil 
supplemented with $\mathrm{CuO}$ ENMs (160 mg/kg) induced substantial changes in the gut microbiota with a significant decrease in the symbiont Candidatus Lumbricincola, but it had no effect on the immune competence (29). Thereby, the gut microbiota might adapt itself in a way (which needs to be demonstrated) that ensures maintaining a proper immune homeostasis.

\section{CONCLUSIONS AND PERSPECTIVES}

To summarize, increasing observations have claimed a link between GIT exposure to ENMs, gut microbiota dysbiosis and intestinal inflammation (Figure 2). Such effects of ENMs are often dosedependent. We acknowledge that in a few cases ENMs could induce microbiota dysbiosis characterized by a decrease in commensals (Lactobacillus, Bacteroides, Bifidobacterium, etc.) and/or an enrichment of other members (E. coli, Shigella, Listeria, etc.), which in turn cause an intestinal inflammation, compromise epithelium integrity and induce IBD-like symptoms (Figure 2). But these works suffer shortcomings and are not relevant for human exposure doses or uptake conditions. By contrast, little or no overt effect on intestinal immunity has been found in a large number of in vivo assays, where ENMs are orally administered in a more realistic dose or fashion. Notably, most in vivo studies investigate the immunotoxicity of ENMs in healthy individuals, while it might be more prominent in those with intestinal inflammation (such as IBD). Indeed, inflammatory symptoms like mucus defects (90), dysfunctional macrophages (91), etc. could increase and extend the exposure of intestinal epithelium to ENMs. Interestingly, the DSSinduced IBD symptoms in mice can be either exacerbated (92) or attenuated (19) following oral intake of ENMs, suggesting that ENM exposure do not necessarily have detrimental consequences, even for those with inflamed intestine. Future works should cover more types of ENMs, simulate the real-life ENM exposure situation, exploit both healthy and inflammatory host model, and draw cautious conclusions.

The in vivo studies on different animal models show extensive variation regarding the ENM effects on gut microbiota or intestinal immunity (Table 1). This may be due to discrepancies in the overall experimental settings (animal species, age, EMN exposure time, dose and uptake manner), the ENM physicochemical nature (size, shape, surface decoration and charge), the possible in vivo bio-transformation of ENMs and the methodology for gut microbiota analysis (Table 1). A unifying exposure model is required.

\section{REFERENCES}

1. De Jong WH, Borm PJA. Drug Delivery and Nanoparticles: Applications and Hazards. Int J Nanomed (2008) 3(2):133-49. doi: 10.2147/ ijn.s596

2. Ge L, Li Q, Wang M, Ouyang J, Li X, Xing MMQ. Nanosilver Particles in Medical Applications: Synthesis, Performance, and Toxicity. Int J Nanomed (2014) 9:2399-407. doi: 10.2147/IJN.S55015

3. Weir A, Westerhoff P, Fabricius L, Hristovski K, Von Goetz N. Titanium Dioxide Nanoparticles in Food and Personal Care Products. Environ Sci Technol (2012) 46(4):2242-50. doi: 10.1021/es204168d
However, pitfalls of current animal models should be considered when translating gut microbiota research results to humans. The murine gut microbiota resembles the human one at phylum level, but differs at genus and species level (93). The anatomy and physiological functions of several GIT segments in the mouse are also different from those of humans (93). Therefore, a future perspective is to establish human models, necessarily in vitro, based on primary cells. To this end, microfluidic intestine-on-chips that can establish a prolonged coculture of human intestinal epithelium and gut microbes could be a promising in vitro human model to evaluate the ENM immunotoxicity $(94,95)$. When supplemented with immune cells, the intestine-on-a-chip could enable us to monitor the dynamics of ENM behavior in the gut tissue, gut microbiota changes, intestinal barrier function, immune cell activation and inflammation, thus providing predictive values on the ENM immunotoxicity. An additional but important point is the variability of gut microbiota, not only inter-individually but also at the intra-individual level (for instance in different health conditions). This calls for the need of a personalized profiling of the ENM effects on gut immunity, as it will depend on the individual microbiota in a given moment. Future immuno-nanosafety models, like the intestine-on-a-chip mentioned above, will therefore need to include the individual microbiota and the innate immune cells (in particular macrophages) derived from the individual subject.

\section{AUTHOR CONTRIBUTIONS}

MT, JQ, and LL devised the study and wrote the manuscript. SL, $\mathrm{LW}$, and $\mathrm{ZH}$ contributed to literature search and gave insightful suggestions in revising this work. All authors contributed to the article and approved the submitted version.

\section{FUNDING}

This work was supported by the National Natural Science Foundation of China (81900071).

\section{ACKNOWLEDGMENTS}

BioRender was used to create schematic representations.

4. Vance ME, Kuiken T, Vejerano EP, Mcginnis SP, Hochella MFJr., Rejeski D, et al. Nanotechnology in the Real World: Redeveloping the Nanomaterial Consumer Products Inventory. Beilstein J Nanotechnol (2015) 6:1769-80. doi: 10.3762/bjnano.6.181

5. Hirt N, Body-Malapel M. Immunotoxicity and Intestinal Effects of Nano- and Microplastics: A Review of the Literature. Part Fibre Toxicol (2020) 17(1):57. doi: 10.1186/s12989-020-00387-7

6. Carrouel F, Viennot S, Ottolenghi L, Gaillard C, Bourgeois D. Nanoparticles as Anti-Microbial, Anti-Inflammatory, and Remineralizing Agents in Oral Care Cosmetics: A Review of the Current Situation. Nanomater (Basel Switzerland) (2020) 10(1):140. doi: 10.3390/nano10010140 
7. Park E-J, Yi J, Kim Y, Choi K, Park K. Silver Nanoparticles Induce Cytotoxicity by a Trojan-Horse Type Mechanism. Toxicol In Vitro (2010) 24(3):872-8. doi: 10.1016/j.tiv.2009.12.001

8. Georgantzopoulou A, Serchi T, Cambier S, Leclercq CC, Renaut J, Shao J, et al. Effects of Silver Nanoparticles and Ions on a Co-Culture Model for the Gastrointestinal Epithelium. Part Fibre Toxicol (2016) 13(1):9. doi: 10.1186/ s12989-016-0117-9

9. Mortensen NP, Moreno Caffaro M, Aravamudhan S, Beeravalli L, Prattipati S, Snyder RW, et al. Simulated Gastric Digestion and In Vivo Intestinal Uptake of Orally Administered $\mathrm{CuO}$ Nanoparticles and $\mathrm{TiO}_{2}$ E171 in Male and Female Rat Pups. Nanomater (Basel Switzerland) (2021) 11(6):1487. doi: $10.3390 /$ nano1 1061487

10. Zolnik BS, GonzíLez-FerníNdez AF, Sadrieh N, Dobrovolskaia MA. Minireview: Nanoparticles and the Immune System. Endocrinology (2010) 151(2):458-65. doi: 10.1210/en.2009-1082

11. Boraschi D, Italiani P, Palomba R, Decuzzi P, Duschl A, Fadeel B, et al. Nanoparticles and Innate Immunity: New Perspectives on Host Defence. Semin Immunol (2017) 34:33-51. doi: 10.1016/j.smim.2017.08.013

12. Dobrovolskaia MA, Shurin M, Shvedova AA. Current Understanding of Interactions Between Nanoparticles and the Immune System. Toxicol Appl Pharmacol (2016) 299:78-89. doi: 10.1016/j.taap.2015.12.022

13. David CA, Owen A, Liptrott NJ. Determining the Relationship Between Nanoparticle Characteristics and Immunotoxicity: Key Challenges and Approaches. Nanomedicine (2016) 11(11):1447-64. doi: 10.2217/nnm-20160017

14. Tlaskalova-Hogenova H, Vetvicka V, Sterzl J, Stepankova R. Development of Immune Potential and Migration Pattern of Cells From Germfree (Gf) and Conventionally (Conv) Reared Rats. Adv Exp Med Biol (1982) 149:515-20. doi: 10.1007/978-1-4684-9066-4_72

15. Li Y, Fujita M, Boraschi D. Endotoxin Contamination in Nanomaterials Leads to the Misinterpretation of Immunosafety Results. Front Immunol (2017) 8:472. doi: $10.3389 /$ fimmu.2017.00472

16. Li Y, Shi Z, Radauer-Preiml I, Andosch A, Casals E, Luetz-Meindl U, et al. Bacterial Endotoxin (Lipopolysaccharide) Binds to the Surface of Gold Nanoparticles, Interferes With Biocorona Formation and Induces Human Monocyte Inflammatory Activation. Nanotoxicology (2017) 11(9-10):115775. doi: $10.1080 / 17435390.2017 .1401142$

17. Van Den Brule S, Ambroise J, Lecloux H, Levard C, Soulas R, De Temmerman PJ, et al. Dietary Silver Nanoparticles Can Disturb the Gut Microbiota in Mice. Part Fibre Toxicol (2016) 13(1):38. doi: 10.1186/s12989-016-0149-1

18. Chen H, Zhao R, Wang B, Cai C, Zheng L, Wang H, et al. The Effects of Orally Administered $\mathrm{Ag}, \mathrm{TiO}_{2}$ and $\mathrm{SiO}_{2}$ Nanoparticles on Gut Microbiota Composition and Colitis Induction in Mice. NanoImpact (2017) 8:80-8. doi: 10.1016/j.impact.2017.07.005

19. Siczek K, Zatorski H, Chmielowiec-Korzeniowska A, Pulit-Prociak J, Smiech M, Kordek R, et al. Synthesis and Evaluation of Anti-Inflammatory Properties of Silver Nanoparticle Suspensions in Experimental Colitis in Mice. Chem Biol Drug Des (2017) 89(4):538-47. doi: 10.1111/cbdd.12876

20. Hadrup N, Loeschner K, Bergstrom A, Wilcks A, Gao X, Vogel U, et al. Subacute Oral Toxicity Investigation of Nanoparticulate and Ionic Silver in Rats. Arch Toxicol (2012) 86(4):543-51. doi: 10.1007/s00204-011-0759-1

21. Wilding LA, Bassis CM, Walacavage K, Hashway S, Leroueil PR, Morishita M, et al. Repeated Dose (28-Day) Administration of Silver Nanoparticles of Varied Size and Coating Does Not Significantly Alter the Indigenous Murine Gut Microbiome. Nanotoxicology (2016) 10(5):513-20. doi: 10.3109/ 17435390.2015 .1078854

22. Li J, Yang S, Lei R, Gu W, Qin Y, Ma S, et al. Oral Administration of Rutile and Anatase Tio2 Nanoparticles Shifts Mouse Gut Microbiota Structure. Nanoscale (2018) 10(16):7736-45. doi: 10.1039/c8nr00386f

23. Chen Z, Han S, Zhou D, Zhou S, Jia G. Effects of Oral Exposure to Titanium Dioxide Nanoparticles on Gut Microbiota and Gut-Associated Metabolism in Vivo. Nanoscale (2019) 11(46):22398-412. doi: 10.1039/ c9nr07580a

24. Pei X, Xiao Z, Liu L, Wang G, Tao W, Wang M, et al. Effects of Dietary Zinc Oxide Nanoparticles Supplementation on Growth Performance, Zinc Status, Intestinal Morphology, Microflora Population, and Immune Response in Weaned Pigs. J Sci Food Agric (2019) 99(3):1366-74. doi: 10.1002/jsfa.9312
25. Xia T, Lai W, Han M, Han M, Ma X, Zhang L. Dietary Zno Nanoparticles Alters Intestinal Microbiota and Inflammation Response in Weaned Piglets. Oncotarget (2017) 8(39):64878-91. doi: 10.18632/oncotarget.17612

26. Chen H, Zhao R, Wang B, Zheng L, Ouyang H, Wang H, et al. Acute Oral Administration of Single-Walled Carbon Nanotubes Increases Intestinal Permeability and Inflammatory Responses: Association With the Changes in Gut Microbiota in Mice. Adv Healthc (2018) 7(13):1701313. doi: 10.1002/ adhm.201701313

27. Mulvey JJ, Littmann ER, Ling L, Mcdevitt MR, Pamer EG, Scheinberg DA. The Effects of Amine-Modified Single-Walled Carbon Nanotubes on the Mouse Microbiota. Int J Nanomed (2018) 13:5275-86. doi: 10.2147/ IJN.S168554

28. Li B, Ding Y, Cheng X, Sheng D, Xu Z, Rong Q, et al. Polyethylene Microplastics Affect the Distribution of Gut Microbiota and Inflammation Development in Mice. Chemosphere (2020) 244:125492. doi: 10.1016/ j.chemosphere.2019.125492

29. Swart E, Dvorak J, Hernádi S, Goodall T, Kille P, Spurgeon D, et al. The Effects of in Vivo Exposure to Copper Oxide Nanoparticles on the Gut Microbiome, Host Immunity, and Susceptibility to a Bacterial Infection in Earthworms. Nanomater (Basel) (2020) 10(7):1337. doi: 10.3390/nano10071337

30. Kamada N, Kim Y-G, Sham HP, Vallance BA, Puente JL, Martens EC, et al. Regulated Virulence Controls the Ability of a Pathogen to Compete With the Gut Microbiota. Science (2012) 336(6086):1325-9. doi: 10.1126/science. 1222195

31. Donohoe DR, Garge N, Zhang X, Sun W, O'connell TM, Bunger MK, et al. The Microbiome and Butyrate Regulate Energy Metabolism and Autophagy in the Mammalian Colon. Cell Metab (2011) 13(5):517-26. doi: 10.1016/ j.cmet.2011.02.018

32. Zheng D, Liwinski T, Elinav E. Interaction Between Microbiota and Immunity in Health and Disease. Cell Res (2020) 30(6):492-506. doi: 10.1038/s41422020-0332-7

33. Belkaid Y, Harrison OJ. Homeostatic Immunity and the Microbiota. Immunity (2017) 46(4):562-76. doi: 10.1016/j.immuni.2017.04.008

34. Albhaisi SM, Bajaj JS, Sanyal AJ. Role of Gut Microbiota in Liver Disease. Am J Physiol Gastrointest Liver Physiol (2020) 318(1):84-98. doi: 10.1152/ ajpgi.00118.2019

35. Morais LH, Schreiber HL, Mazmanian SK. The Gut Microbiota-Brain Axis in Behaviour and Brain Disorders. Nat Rev Microbiol (2021) 19(4):241-55. doi: 10.1038/s41579-020-00460-0

36. Rooks MG, Garrett WS. Gut Microbiota, Metabolites and Host Immunity. Nat Rev Immunol (2016) 16(6):341-52. doi: 10.1038/nri.2016.42

37. Wang G, Huang S, Wang Y, Cai S, Yu H, Liu H, et al. Bridging Intestinal Immunity and Gut Microbiota by Metabolites. Cell Mol Life Sci (2019) 76 (20):3917-37. doi: 10.1007/s00018-019-03190-6

38. Thaiss CA, Zmora N, Levy M, Elinav E. The Microbiome and Innate Immunity. Nature (2016) 535(7610):65-74. doi: 10.1038/nature18847

39. Honda K, Littman DR. The Microbiota in Adaptive Immune Homeostasis and Disease. Nature (2016) 535(7610):75-84. doi: 10.1038/nature18848

40. Den Besten G, Van Eunen K, Groen AK, Venema K, Reijngoud D-J, Bakker BM. The Role of Short-Chain Fatty Acids in the Interplay Between Diet, Gut Microbiota, and Host Energy Metabolism. J Lipid Res (2013) 54(9):2325-40. doi: 10.1194/jlr.R036012

41. Heine H, Rietschel ET, Ulmer AJ. The Biology of Endotoxin. Mol Biotechnol (2001) 19(3):279-96. doi: 10.1385/MB:19:3:279

42. Macia L, Tan J, Vieira AT, Leach K, Stanley D, Luong S, et al. MetaboliteSensing Receptors Gpr43 and Gpr109a Facilitate Dietary Fibre-Induced Gut Homeostasis Through Regulation of the Inflammasome. Nat Commun (2015) 6(1):6734. doi: 10.1038/ncomms7734

43. Wrzosek L, Miquel S, Noordine M-L, Bouet S, Chevalier-Curt MJ, Robert V, et al. Bacteroides Thetaiotaomicron and Faecalibacterium Prausnitzii Influence the Production of Mucus Glycans and the Development of Goblet Cells in the Colonic Epithelium of a Gnotobiotic Model Rodent. BMC Biol (2013) 11(1):61. doi: 10.1186/1741-7007-11-61

44. Fusunyan RD, Nanthakumar NN, Baldeon ME, Walker WA. Evidence for an Innate Immune Response in the Immature Human Intestine: Toll-Like Receptors on Fetal Enterocytes. Pediatr Res (2001) 49(4):589-93. doi: 10.1203/00006450-200104000-00023 
45. Molgora M, Barajon I, Mantovani A, Garlanda C. Regulatory Role of Il-1r8 in Immunity and Disease. Front Immunol (2016) 7:149. doi: 10.3389/ fimmu.2016.00149

46. Parada Venegas D, de la Fuente MK, Landskron G, González MJ, Quera R, Dijkstra G, et al. Short Chain Fatty Acids (Scfas)-Mediated Gut Epithelial and Immune Regulation and Its Relevance for Inflammatory Bowel Diseases. Front Immunol (2019) 10:277. doi: 10.3389/fimmu.2019.00277

47. Fachi JL, Felipe JDS, Pral LP, Da Silva BK, Corrêa RO, De Andrade MCP, et al. Butyrate Protects Mice From Clostridium Difficile-Induced Colitis Through an Hif-1-Dependent Mechanism. Cell Rep (2019) 27(3):750-61.e7. doi: 10.1016/ j.celrep.2019.03.054

48. Moore R, Pothoulakis C, Lamont JT, Carlson S, Madara JL. C. Difficile Toxin a Increases Intestinal Permeability and Induces Cl- Secretion. Am J Physiol Gastrointest Liver Physiol (1990) 259(2):G165-G72. doi: 10.1152/ajpgi. 1990.259.2.G165

49. Karve SS, Pradhan S, Ward DV, Weiss AA. Intestinal Organoids Model Human Responses to Infection by Commensal and Shiga Toxin Producing Escherichia Coli. PloS One (2017) 12(6):e0178966. doi: 10.1371/ journal.pone.0178966

50. Guo S, Al-Sadi R, Said HM, Ma TY. Lipopolysaccharide Causes an Increase in Intestinal Tight Junction Permeability In Vitro and In Vivo by Inducing Enterocyte Membrane Expression and Localization of Tlr-4 and Cd14. Am J Pathol (2013) 182(2):375-87. doi: 10.1016/j.ajpath.2012.10.014

51. Qiu J, Heller JJ, Guo X, Chen Z-ME, Fish K, Fu Y-X, et al. The Aryl Hydrocarbon Receptor Regulates Gut Immunity Through Modulation of Innate Lymphoid Cells. Immunity (2012) 36(1):92-104. doi: 10.1016/ j.immuni.2011.11.011

52. Martinez FO, Sica A, Mantovani A, Locati M. Macrophage Activation and Polarization. Front Biosci (2008) 13(2):453-61. doi: 10.2741/2692

53. Ji J, Shu D, Zheng M, Wang J, Luo C, Wang Y, et al. Microbial Metabolite Butyrate Facilitates M2 Macrophage Polarization and Function. Sci Rep (2016) 6(1):24838. doi: 10.1038/srep24838

54. Smith PD, Smythies LE, Shen R, Greenwell-Wild T, Gliozzi M, Wahl SM. Intestinal Macrophages and Response to Microbial Encroachment. Mucosal Immunol (2011) 4(1):31-42. doi: 10.1038/mi.2010.66

55. Singh N, Gurav A, Sivaprakasam S, Brady E, Padia R, Shi H, et al. Activation of Gpr109a, Receptor for Niacin and the Commensal Metabolite Butyrate, Suppresses Colonic Inflammation and Carcinogenesis. Immunity (2014) 40 (1):128-39. doi: 10.1016/j.immuni.2013.12.007

56. Granucci F, Ferrero E, Foti M, Aggujaro D, Vettoretto K, Ricciardi-Castagnoli P. Early Events in Dendritic Cell Maturation Induced by Lps. Microbes Infect (1999) 1(13):1079-84. doi: 10.1016/S1286-4579(99)00209-9

57. Singh N, Thangaraju M, Prasad PD, Martin PM, Lambert NA, Boettger T, et al. Blockade of Dendritic Cell Development by Bacterial Fermentation Products Butyrate and Propionate Through a Transporter (Slc5a8)Dependent Inhibition of Histone Deacetylases. J Biol Chem (2010) 285 (36):27601-8. doi: 10.1074/jbc.M110.102947

58. Liu L, Li L, Min J, Wang J, Wu H, Zeng Y, et al. Butyrate Interferes With the Differentiation and Function of Human Monocyte-Derived Dendritic Cells. Cell Mol Immunol (2012) 277(1):66-73. doi: 10.1016/j.cellimm.2012.05.011

59. Park J, Kim M, Kang SG, Jannasch AH, Cooper B, Patterson J, et al. ShortChain Fatty Acids Induce Both Effector and Regulatory T Cells by Suppression of Histone Deacetylases and Regulation of the Mtor-S6k Pathway. Mucosal Immunol (2015) 8(1):80-93. doi: 10.1038/mi.2014.44

60. Smith PM, Howitt MR, Panikov N, Michaud M, Gallini CA, Bohlooly -M, et al. The Microbial Metabolites, Short-Chain Fatty Acids, Regulate Colonic $\mathrm{T}_{\text {reg }}$ Cell Homeostasis. Science (2013) 341(6145):569-73. doi: 10.1126/ science. 1241165

61. Kim M, Qie Y, Park J. And Kim Chang H. Gut Microbial Metabolites Fuel Host Antibody Responses. Cell Host Microbe (2016) 20(2):202-14. doi: 10.1016/j.chom.2016.07.001

62. Palm NW, De Zoete MR, Cullen TW, Barry NA, Stefanowski J, Hao L, et al. Immunoglobulin a Coating Identifies Colitogenic Bacteria in Inflammatory Bowel Disease. Cell (2014) 158(5):1000-10. doi: 10.1016/j.cell.2014.08.006

63. Smetana AB, Klabunde KJ, Marchin GR, Sorensen CM. Biocidal Activity of Nanocrystalline Silver Powders and Particles. Langmuir (2008) 24(14):745764. doi: 10.1021/la800091y
64. Guerrero Correa M, Martínez FB, Vidal CP, Streitt C, Escrig J, De Dicastillo CL. Antimicrobial Metal-Based Nanoparticles: A Review on Their Synthesis, Types and Antimicrobial Action. Beilstein J Nanotechnol (2020) 11:1450-69. doi: 10.3762/bjnano.11.129

65. Park H, Kim JY, Kim J, Lee J, Hahn J, Gu MB, et al. Silver-Ion-Mediated Reactive Oxygen Species Generation Affecting Bactericidal Activity. Water Res (2009) 43(4):1027-32. doi: 10.1016/j.watres.2008.12.002

66. Gulbagca F, Ozdemir S, Gulcan M, Sen F. Synthesis and Characterization of Rosa Canina-Mediated Biogenic Silver Nanoparticles for Anti-Oxidant, Antibacterial, Antifungal, and DNA Cleavage Activities. Heliyon (2019) 5 (12):e02980. doi: 10.1016/j.heliyon.2019.e02980

67. Borcherding J, Baltrusaitis J, Chen H, Stebounova L, Wu C-M, Rubasinghege G, et al. Iron Oxide Nanoparticles Induce Pseudomonas Aeruginosa Growth, Induce Biofilm Formation, and Inhibit Antimicrobial Peptide Function. Environ Sci Nano (2014) 1(2):123-32. doi: 10.1039/C3EN00029J

68. Lahiani MH, Gokulan K, Williams K, Khare S. Impact of Pristine Graphene on Intestinal Microbiota Assessed Using a Bioreactor-Rotary Cell Culture System. ACS Appl Mater Interfaces (2019) 11(29):25708-19. doi: 10.1021/ acsami.9b07635

69. Fröhlich EE, Fröhlich E. Cytotoxicity of Nanoparticles Contained in Food on Intestinal Cells and the Gut Microbiota. Int J Mol Sci (2016) 17(4):509. doi: 10.3390/ijms17040509

70. Xie Y, Wu B, Zhang X-X, Yin J, Mao L, Hu M. Influences of Graphene on Microbial Community and Antibiotic Resistance Genes in Mouse Gut as Determined by High-Throughput Sequencing. Chemosphere (2016) 144:1306-12. doi: 10.1016/j.chemosphere.2015.09.076

71. Zhang Y, Mortimer M, Guo L-H. Interplay Between Engineered Nanomaterials and Microbiota. Environ Sci Nano (2020) 7(9):2454-85. doi: 10.1039/D0EN00557F

72. Lamas B, Martins Breyner N, Houdeau E. Impacts of Foodborne Inorganic Nanoparticles on the Gut Microbiota-Immune Axis: Potential Consequences for Host Health. Part Fibre Toxicol (2020) 17(1):19. doi: 10.1186/s12989-02000349-Z

73. Das P, Mcdonald J, Petrof E, Allen-Vercoe E, Walker V. Nanosilver-Mediated Change in Human Intestinal Microbiota. J Nanomed Nanotechnol (2014) 5:235. doi: 10.4172/2157-7439.1000235

74. Cattò C, Garuglieri E, Borruso L, Erba D, Cristina M, Cappitelli F, et al. Impacts of Dietary Silver Nanoparticles and Probiotic Administration on the Microbiota of an in-Vitro Gut Model. Environ Pollut (2018) 245:754-63. doi: 10.1016/j.envpol.2018.11.019

75. Fondevila M, Herrer R, Casallas MC, Abecia L, Ducha JJ. Silver Nanoparticles as a Potential Antimicrobial Additive for Weaned Pigs. Anim Feed Sci Technol (2009) 150(3):259-69. doi: 10.1016/j.anifeedsci.2008.09.003

76. Marambio-Jones C, Hoek EMV. A Review of the Antibacterial Effects of Silver Nanomaterials and Potential Implications for Human Health and the Environment. J Nanopart Res (2010) 12(5):1531-51. doi: 10.1007/s11051010-9900-y

77. Qin J, Li R, Raes J, Arumugam M, Burgdorf KS, Manichanh C, et al. A Human Gut Microbial Gene Catalogue Established by Metagenomic Sequencing. Nature (2010) 464(7285):59-65. doi: 10.1038/nature08821

78. Brooks AW, Priya S, Blekhman R, Bordenstein SR. Gut Microbiota Diversity Across Ethnicities in the United States. PloS Biol (2018) 16(12):e2006842-e. doi: 10.1371/journal.pbio.2006842

79. Fan Y, Pedersen O. Gut Microbiota in Human Metabolic Health and Disease. Nat Rev Microbiol (2021) 19(1):55-71. doi: 10.1038/s41579-020-0433-9

80. Shapiro JM, Subedi S, Leleiko NS. Inflammatory Bowel Disease. Pediatr Rev (2016) 37(8):337-47. doi: 10.1542/pir.2015-0110

81. Nishida A, Inoue R, Inatomi O, Bamba S, Naito Y, Andoh A. Gut Microbiota in the Pathogenesis of Inflammatory Bowel Disease. J Clin Gastroenterol (2018) 11(1):1-10. doi: 10.1007/s12328-017-0813-5

82. Lepper P, Held T, Schneider E, Bölke E, Gerlach H, Trautmann M. Clinical Implications of Antibiotic-Induced Endotoxin Release in Septic Shock. J Intensive Care Med (2002) 28(7):824-33. doi: 10.1007/s00134-002-1330-6

83. Neal MD, Leaphart C, Levy R, Prince J, Billiar TR, Watkins S, et al. Enterocyte Tlr4 Mediates Phagocytosis and Translocation of Bacteria Across the Intestinal Barrier. J Immunol (2006) 176(5):3070-9. doi: 10.4049/ jimmunol.176.5.3070 
84. Elena G, Giovanna D, Brunella P, De Anna F, Alessandro M, Antonietta TM. Proinflammatory Signal Transduction Pathway Induced by Shigella Flexneri Porins in Caco-2 Cells. Braz J Microbiol (2009) 40(3):701-13. doi: 10.1590/ S1517-838220090003000036

85. Ray A, Biswas T. Porin of Shigella Dysenteriae Enhances Toll-Like Receptors 2 and 6 of Mouse Peritoneal B-2 Cells and Induces the Expression of Immunoglobulin $\mathrm{M}$, Immunoglobulin G2a and Immunoglobulin A. Immunology (2005) 114(1):94-100. doi: 10.1111/j.1365-2567.2004.02002.x

86. Song WS, Jeon YJ, Namgung B, Hong M, Yoon S-I. A Conserved Tlr5 Binding and Activation Hot Spot on Flagellin. Sci Rep (2017) 7(1):40878. doi: 10.1038/ srep40878

87. Li J, Cha R, Zhao X, Guo H, Luo H, Wang M, et al. Gold Nanoparticles Cure Bacterial Infection With Benefit to Intestinal Microflora. ACS Nano (2019) 13 (5):5002-14. doi: 10.1021/acsnano.9b01002

88. Liu J-H, Ma X, Xu Y, Tang H, Yang S-T, Yang Y-F, et al. Low Toxicity and Accumulation of Zinc Oxide Nanoparticles in Mice After 270-Day Consecutive Dietary Supplementation. Toxicol Res (2017) 6:134-43. doi: 10.1039/c6tx00370b

89. Swart E, Goodall T, Kille P, Spurgeon DJ, Svendsen C. The Earthworm Microbiome Is Resilient to Exposure to Biocidal Metal Nanoparticles. Environ Pollut (2020) 267:115633. doi: 10.1016/j.envpol.2020.115633

90. Johansson MEV. Mucus Layers in Inflammatory Bowel Disease. Inflamm Bowel Dis (2014) 20(11):2124-31. doi: 10.1097/mib.0000000000000117

91. Na YR, Stakenborg M, Seok SH, Matteoli G. Macrophages in Intestinal Inflammation and Resolution: A Potential Therapeutic Target in Ibd. Nat Rev Gastroenterol Hepatol (2019) 16(9):531-43. doi: 10.1038/s41575-0190172-4

92. Ogawa T, Okumura R, Nagano K, Minemura T, Izumi M, Motooka D, et al. Oral Intake of Silica Nanoparticles Exacerbates Intestinal Inflammation. Biochem Biophys Res Commun (2021) 534:540-6. doi: 10.1016/j.bbrc.2020.11.047
93. Nguyen TLA, Vieira-Silva S, Liston A, Raes J. How Informative Is the Mouse for Human Gut Microbiota Research? Dis Model Mech (2015) 8(1):1-16. doi: $10.1242 / \mathrm{dmm} .017400$

94. Jalili-Firoozinezhad S, Gazzaniga FS, Calamari EL, Camacho DM, Fadel CW, Bein A, et al. A Complex Human Gut Microbiome Cultured in an Anaerobic Intestine-on-a-Chip. Nat BioMed Eng (2019) 3(7):520-31. doi: 10.1038/ s41551-019-0397-0

95. Huh D, Kim HJ, Fraser JP, Shea DE, Khan M, Bahinski A, et al. Microfabrication of Human Organs-on-Chips. Nat Protoc (2013) 8 (11):2135-57. doi: 10.1038/nprot.2013.137

Conflict of Interest: The authors declare that the research was conducted in the absence of any commercial or financial relationships that could be construed as a potential conflict of interest.

The Editor declared a shared affiliation with some of the authors MT, LW, JQ, LL at the time of review.

Publisher's Note: All claims expressed in this article are solely those of the authors and do not necessarily represent those of their affiliated organizations, or those of the publisher, the editors and the reviewers. Any product that may be evaluated in this article, or claim that may be made by its manufacturer, is not guaranteed or endorsed by the publisher.

Copyright (c) 2021 Tang, Li, Wei, Hou, Qu and Li. This is an open-access article distributed under the terms of the Creative Commons Attribution License (CC BY). The use, distribution or reproduction in other forums is permitted, provided the original author(s) and the copyright owner(s) are credited and that the original publication in this journal is cited, in accordance with accepted academic practice. No use, distribution or reproduction is permitted which does not comply with these terms. 